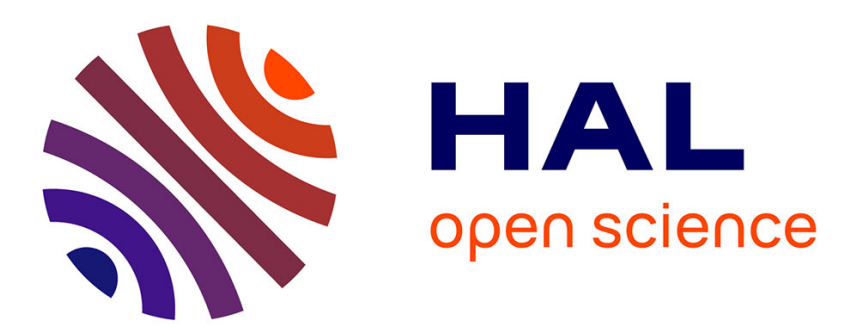

\title{
Behaviorally-based disorders: the historical social construction of youths' most prevalent psychiatric diagnoses
}

\author{
Christopher A. Mallett
}

\section{To cite this version:}

Christopher A. Mallett. Behaviorally-based disorders: the historical social construction of youths' most prevalent psychiatric diagnoses. History of Psychiatry, 2006, 17 (4), pp.437-460. 10.1177/0957154X06063760 . hal-00570858

\section{HAL Id: hal-00570858 \\ https://hal.science/hal-00570858}

Submitted on 1 Mar 2011

HAL is a multi-disciplinary open access archive for the deposit and dissemination of scientific research documents, whether they are published or not. The documents may come from teaching and research institutions in France or abroad, or from public or private research centers.
L'archive ouverte pluridisciplinaire HAL, est destinée au dépôt et à la diffusion de documents scientifiques de niveau recherche, publiés ou non, émanant des établissements d'enseignement et de recherche français ou étrangers, des laboratoires publics ou privés. 


\title{
Behaviorally-based disorders: the historical social construction of youths' most prevalent psychiatric diagnoses
}

\author{
CHRISTOPHER A. MALLETT* \\ Cleveland State University
}

\begin{abstract}
Psychiatry in the USA controls the definitions of mental health disorders and diagnosis through required practice utilization of the Diagnostic and Statistical Manual of Mental Disorders (DSM) and fiscal reimbursement using it. The present sociohistorical research paper presents and critically examines the Manual's systemic and diagnostic development of today's most prevalent youth mental health diagnoses (conduct and oppositional defiant disorders). Through a social construction theoretical paradigm, this research identified diagnostic classification systems, nosology changes, critical time periods, conducive social and cultural conditions, and key individuals involved in the development of these youth behaviorally-based disorders within two distinct historical time frames: 1880 to 1968 and 1969 to 2000. It also identified patterns of nosology system and diagnostic category changes based upon very limited empiricism, inordinately influenced by a limited number of individuals, and understood through a socially constructed framework.
\end{abstract}

Keywords: behaviorally-based; diagnosis; history; mental health; nosology; psychiatry; social construction; youth

Mental health diagnosis in the USA has become, over time, a medical and psychiatric domain. Today, mental health service delivery requires psychiatric diagnosis for public or private access and fiscal reimbursement (Cooper, 2004; Frank and Manning, 1992). The Diagnostic and Statistical Manual of

* Address for correspondence: School of Social Work, Cleveland State University, 2121 Euclid Avenue, \#CB324, Cleveland, Ohio 44115-2214, USA. Email: c.a.mallett@csuohio.edu 
Mental Disorders (DSM; APA, 1994) has become the predominant and required psychiatric measurement tool (Kirk and Kutchins, 1992).

Authors have critiqued and questioned the DSM's current diagnostic and categorical construction (Berrios, 1996; Caplan, 1995; Kirk and Kutchins, 1986, 1992; Restivo and Loughlin, 1987; van Praag, 1993). However, no analysis of youth psychiatric diagnostic systems or aetiology of behaviorallybased $^{1}$ disorders exists. The present review is therefore important because published epidemiology literature within the USA from 1982 to 2004, which measured diagnostic prevalence rates with the DSM criteria for at-risk youths (ages 9-17), reported rates in two populations with means of $27 \%$ and $53 \%$ for conduct disorder and $12 \%$ in both for oppositional defiant disorder; see Appendix (p. 460). The purpose of this study is to identify what is known, to investigate how this knowledge was acquired and to understand how youth behaviorally-based psychiatric disorders were defined over time.

Historical analysis research methodology generates coherent explanations of the past, understands constructs through emergent designs, discerns knowledge from rhetoric, utilizes well-placed scepticism and identifies comparative patterns (Barzun and Graff, 1987; Carr, 1961; Krathwohl, 1992; Rubin and Babbie, 2000; Zinn, 1970). This paper first presents a critical/social construction theoretical framework for making a historical review of youth psychiatric measurement nosology developments. Second, the nineteenthcentury emergence of 'youth' as a social category is reviewed, as this development allowed the subsequent establishment of psychiatric nosologies. Third, diagnostic classification systems and definitions of youth behaviorally-based disorders from two time periods $(1880-1968,1969-2000)$ are reviewed, identifying nosology system changes, critical time frames and key individuals involved. Finally, the historical findings are critiqued.

\section{Critical/social construction theoretical framework}

Critical theory disagrees with the legitimizing process of power formations within institutions and proposes an alternative conception of social science be required. This conception incorporates both the historical totality of society and the belief that this analysis could not be indifferent or value-free and should engage within the process of change. This theory presents an 'attitude of antagonism and critique in the face of deeply problematic contemporary social formation' (Poster, 1989: 3).

Jurgen Habermas expanded this theoretical sphere to include a specific focus on questioning these power formations (McCarthy, 1978). He introduced a definition of 'public sphere', separate from the private interests, as a medium of reform; argued that in capitalism the state enters the economy and puts in crisis the legitimacy of the state by politicizing economic issues; claimed that science is integrated into the economy and becomes part of the ideology; and pursued a revision for increased public discussion and consciousness. 
This social construction framework is furthered in that many solidly established 'scientific facts' are undeniably linked in their development to prescientific, somewhat hazy, related pre-ideas. Even the modern concept of the disease entity is an outcome of such a development and is by no means the only logical possibility (Fleck, 1935; Malinowski, 1954). Individuals in society have been trained to believe that knowledge arises from a process of drawing lines, making distinctions and seeing meaning as a definition (Dumont, 1984). If these distinctions and definitions were created and not discovered, how is the psychiatric field certain of correct classifications (Szasz, 1994)?

\section{Youth as a social category in the USA: 1870-1910}

During the later nineteenth century, psychiatry, with a focus on children and youth, emerged as a distinct field within medicine, expanding beyond the state institutions and propelled by other significant social and cultural trends (Grob, 1994). These trends included: the emergence of the mental health field; the establishment of the non-profit social service profession; the rise of the educational profession, with high school and vocational guidance expansion; the origination of juvenile delinquency, and establishment of juvenile courts; the growth of Christian youth movements; the inauguration of the childstudy movement; and the establishment of adolescence as a distinct developmental stage (Church, 1976; Hall, 1893, 1904; Kett, 1977; Platt, 1969).

The child-study movement arguably led to this distinct developmental category of adolescence. This categorized social definition of an entire age group became a natural fit for psychiatry during its emergence within the medical field. Hall (1904), influenced by Darwin, Nietzsche, Spencer and Haeckel, found this youth stage a normal outgrowth of biological maturation and its accompanying faults as outgrowths of instinctive urges. Hall's seminal pursuit of the unique adolescent developmental category was reinforced by the high-school education social organization and youth movements of this time (Chapman and Counts, 1924; Neubauer, 1992).

The interest in adolescence as a distinct developmental period led to new ways of regulating youth behavior, as evidenced by the growth of the mental health field and juvenile courts throughout the country. This conception and regulation of behavior was imposed on youth from the fields of psychology and biology in the invention of the adolescent (Kett, 1977). During this era, the psychiatric field's expansion was moved forward on these biological and Freudian tenets.

Numerous theorists and psychiatrists reinforced and incorporated this developmental stage into their disparate psychologies, lending continued credence to the legitimacy and incorporation into psychiatry of the youth developmental category (Kett, 1977). Freud (1905) acknowledged adolescence not as a primary psychoanalytic stage but one in which earlier childhood neurosis were repeated. Adler viewed adolescence as a significantly more 
important development, but reinforced male societal gender hierarchies in psychiatric application (Neubauer, 1992). This new adolescent stage and accompanying freedom from adult demands was limited by existing economic and scientific orders. Hall's principle - that inherited biological traits emerged during adolescence - reinforced this social order; Hall regarded his own theoretical adolescent norms as natural and deviations from them as 'abnormal' (Hall, 1904; Neubauer, 1992). It is this conception of 'abnormal' that overlapped with Freud's theoretical applications and reinforced the development of youth psychiatric diagnoses and nosology systems.

\section{Developments from 1880 to 1968}

\section{$D S M-I$ and $D S M-I I$}

Limited psychiatric noslogy systems existed early in this period; however, youth psychiatric diagnostic categories were first evidenced in 1886: the first reference to youth was a demarcation of 'idiotic' and 'imbecile' children within institutions (New York Medico-Legal Society, 1886). The Association of Medical Superintendents of American Institutions of the Insane, precursor to the American Psychiatric Association, produced the first standardized psychiatric nosology after several conferences and recommendations from leading psychiatrists in the field. Diagnoses were categorized into 22 principle groups with the youth demarcation for those younger than 15 years of age (Statistical Manual, 1917). The Statistical Manual for the Use of Hospitals for Mental Diseases, ${ }^{2}$ which was published in 10 editions (U.S. Census Bureau, 1918-1942), was the precursor to the Diagnostic and Statistical Manual of Mental Disorders (DSM). The 8th edition first published the category 'Primary Behavior Disorders' for youth, which included 'habit disturbance', 'conduct disturbance' and 'neurotic traits'.

Numerous competing and regional diagnostic systems were utilized during this early period. A consortium of organizations ${ }^{3}$ recognized the disparity and regionalism of psychiatric nomenclature and worked together to produce the Standard Nomenclature of Diseases (1933-1952). This consortium followed the League of Nations' recommendation for countries to standardize their illness nomenclature (Logie, 1933). The American Psychiatric Association was not formally part of this nomenclature development, but did provide the diagnostic framework of 'habit disturbance', 'conduct disturbance' and 'neurotic traits' as childhood categories.

The 4th edition of the Standard Nomenclature of Diseases (1952) was published in the same year as the DSM (first edition) was released by the American Psychiatric Association. George Raines, chairman of the APA's Committee on Nomenclature and Statistics, was the central figure bridging these publications and mirroring their presentations. Through his chairmanship, Raines (and the APA) successfully incorporated the DSM material into 
the larger nomenclature on diseases aimed at the medical community as a whole. This Standard Nomenclature (4th edition) incorporated the mental deficiency rating system and 'transient situational personality' disorders wherein the childhood and adolescent adjustment reaction of 'conduct disturbance' was found (Plunkett and Hayden, 1952).

In 1950 the APA's Committee on Nomenclature and Statistics designed, with assistance from the National Institute of Mental Health (Biometrics Branch), a revision of the 10th edition of The Statistical Manual for the Use of Hospitals for Mental Diseases (U.S. Census Bureau, 1942). A survey of only $10 \%$ of the APA's membership $(N=241)$ identified a $72 \%$ utilization rate. With this simple survey a recommendation for adoption of the Manual was made and accepted at the APA's annual meeting on 6 November 1950. All the members of the Committee were also assigned the work for the Standard Classified Nomenclature of Diseases and Pathological Conditions, Injuries, and Poisonings for the United States (3rd, 1950, and 4th editions, 1956).

The Diagnostic and Statistical Manual of Mental Disorders (1952) listed childhood and adolescent disorders under the heading 'transient situational personality disorders'. This category further delineated 'adjustment reaction of childhood' (which included the aforementioned 'habit disturbance', 'conduct disturbance' and 'neurotic traits') and 'adjustment reaction of adolescence', with no subcategories. This first DSM cited no published references supporting the childhood and adolescent typology, but relied on Ackerson $(1932,1942)$, Hewitt and Jenkins (1946) and Pearson (1949) for authoritative categorization. Ackerson (1932) reviewed 5000 case files of youth admitted to the Illinois Institute for Juvenile Research and used his own clinical judgement to delineate all behavior traits noted. Hewitt and Jenkins (1946) reviewed 500 case files, but predetermined three categories for youth prior to data collection. These categories were determined conclusive and included 'unsocialized aggressive behavior', 'socialized delinquent behavior' and 'over-inhibited behavior'. Pearson (1949) postulated, through case example, 'temper tantrums', 'anti-social character' and 'delinquency' as categories.

In 1964 the American Psychiatric Association published the Diagnostic Classification in Child Psychiatry (APA report \#18). This document encapsulated conference proceedings sponsored by the APA's Committee on Research and discussed proposed changes in the diagnostic system for behaviorallybased childhood and adolescent disorders. The report stated the need for one comprehensive diagnostic system and that 'the increase in scientific knowledge does not yet permit a comprehensive statement of diagnostic and etiological principles, we are nevertheless firmly on the road to discerning some of the basic concepts needed for the task' (Jenkins, 1964: 2). References cited as an inclusive review of this conference's scientific knowledge included only Ackerman (1953), Brown ... (1937), Cameron (1955), Dreger (1964) and GAP (1957). Based on this referenced support, the APA report recommended the inclusion of 'oppositional personality' and 'anti-social personality'. 
Brown ... Classification System (1937) listed characteristics but provided no supportive references. Ackerman (1953) cited support from Brown ... (1937) and Pearson Nosology (1920), and presented an extended discussion of previous diagnostic categories, but provided no additional data. Cameron (1955) presented no additional data and reiterated past studies by Burt (1937), Hall (1948) and Kanner (1935). Selbach (1960) summarized all international classification of diseases for behavioral-based terminology, but also presented no analysis or data to review. The GAP Report \#38 (1957) discussed: the clinical premise of presenting problems; the physical, psychological, and psychiatric examination; diagnostic formulation; plans and prognosis; and only an abstract presentation of possibilities in the diagnostic field. Dreger (1964) collected demographic and parental behavioral complaint checklist data for youth, ages six to thirteen.

Numerous different and competing nosology systems were introduced, but they failed to attract a significant utilization and following (Beller, 1962; Cameron, 1955; Chess, 1959; Hutt and Gibby, 1957; Jenson, 1959; Rose, 1958; Selbach, 1960; Standard Nomenclature, 5th edn, 1961; WHO, 1957). In its 8th revision of the International Classification of Diseases $(I C D)$, the WHO cited only 'committee collaboration' as the source for proposed changes (WHO, 1965). This twelve-person committee, one member each from different countries, reviewed unpublished working papers of case histories for twelve children and used an inter-rater reliability procedure to find 'remarkably good agreement on the broad categories of diagnosis' (WHO, 1965: ix). This ICD 8th revision was made after a review of only seven videotaped cases with a completed, accompanying questionnaire (Rutter, 1969). Based on only this methodology, changes were made to the delinquency section of youth behaviorally-based disorders.

Although DSM was not extensively used at first, by the time the 2 nd edition (DSM-II, APA, 1968) was published, this Manual had become the most widely endorsed, promoted and, eventually, used psychiatric nosology. The APA said the DSM-II revision was necessary, in order to comply with $I C D-8$. In February 1967 it took only one further review of the DSM-I step by circulating the DSM-II draft (with changes) to 120 psychiatrists requesting specific suggestions to eliminate errors and to improve statement quality. The responses included 'many valuable replies' (APA, 1968: ix.) No further references were published. The DSM-II listed 'Behavior Disorders of Children and Adolescence' with five subcategories: hyperkinetic reaction of childhood (or adolescence); overanxious reaction; unsocialized aggressive reaction, characterized by overt or covert hostile disobedience, vengefulness, physical and verbal aggressiveness, temper tantrums, solitary stealing, lying, and hostile teasing; group delinquent reaction, characterized by acquiring values and behaviors of a delinquent peer group or gang to whom they are loyal; and other reaction of childhood or adolescence (APA, 1968). 


\section{Key individuals}

During this period, a number of individuals emerged as inordinately influential in the progression of the $D S M$ classification system for behaviorally-based youth disorders (see Table 1). These individuals attained positions of authority and power through being first to publish some acceptable nosology system that was found usable in practice, or through the authoring of some published data and analysis, or, through fortunate timing, by being in a position of authority when these nosology definition and utilization decisions were made.

Citations by other authors to Luton Ackerson's two studies were the most numerous within the referenced literature, followed by citations to Richard Jenkins, but the latter was far more prolific and collaborative. These two authors were exponentially cited by later writers as guideposts to the early diagnostic classifications. Donald Peterson and Herbert Quay were equally dominant in their research on delinquency and introduced a relied-upon punitive framework for viewing these youth behaviors. George Raines served as the first Chairman of the APA's Committee on Nomenclature and Statistics which was given the authority to produce the necessary categorical data and research for the first DSM (APA, 1952). Raines also served as the liaison from the American Psychiatric Association in reporting necessary categorization to the American Medical Association's 'Nomenclature of

TABLE 1. Key individuals in the period 1880-1968

\begin{tabular}{lccl}
\hline & Citations $^{\mathrm{a}}$ & Publications $^{\mathrm{b}}$ & $\begin{array}{l}\text { Committees/task } \\
\text { forces/work groups }\end{array}$ \\
\hline Luton Ackerson & 31 & 2 & A B \\
Richard Jenkins & 24 & 11 & G \\
Herbert Quay & 11 & 9 & A (Chair) \\
Donald Peterson & 10 & 9 & \\
Michael Rutter & & & \\
George Raines & & & \\
\hline
\end{tabular}

a Number of citations from published sources (DSM nosology).

b This tally includes the number of publications by each author that were part of the material used by the APA as research supporting the changes to the DSM (I and II). In total, 86 possible publications were referenced by the APA during this period.

c A. Committee on Nomenclature and Statistics (1972-75)

B. GAP's Committee on Child Psychiatry (1967-70)

G. Subcommittee on Disruptive Behavior Disorders (1985-87) 
Diseases', the dominant health directory of the era. Michael Rutter's contributions to the World Health Organization served as a nosology framework incorporated by the APA. However, one additional committee member, Robert Spitzer, will emerge as most dominant in the next historical $D S M$ era.

\section{Developments from 1969 to 2000}

At this historical marker, the field of psychiatry was poised for significant expansion and dominance within mental health. This dominance converged through numerous societal and policy trends and included: the establishment of significant federal public spending on health care (Medicaid and Medicare, established in 1965); the explosion of health care spending in the economy as a whole (1980 to present); the acceptance of one psychiatric nosology system necessary for public and private access and fiscal reimbursement for mental health services; and, more poignantly, the general societal acceptance of mental difficulties as 'mental illness' or 'mental disease' with a genetic or biological aetiology (Grob, 1994; Kirk and Kutchins, 1992; Mechanic, 1999).

\section{DSM-III}

A dramatic change from dynamic to descriptive categorization within psychiatric nosology occurred from the DSM-II (in 1968) to the introduction of the DSM-III (in 1980). Reliance on the ICD-8 (WHO, 1965) was discounted, with the introduction of a multi-axial classification system. Support for this system was limited to one earlier published classification review (Rutter, 1969) and a report denigrating the ICD-9's methodology, citing a need for improved reliability and validity of diagnostic categories by the APA (DSM-III; APA, 1980). Numerous associations ${ }^{4}$ joined the Task Force on Nomenclature and Statistics in promotion of a descriptive categorization change, but I identified no additional reliability or validity studies from the DSM-III construction.

The DSM-III greatly expanded childhood and adolescent diagnostic categories, increasing from 2 to 65 pages of the Manual. For the first time, it differentiated conduct and oppositional disorders. Conduct disorder was expanded to five separate diagnostic types for those under 18 years of age: undersocialized aggressive; ${ }^{5}$ socialized aggressive $;^{6}$ undersocialized nonaggressive $;^{7}$ socialized nonaggressive; and atypical conduct disorder. ${ }^{8}$ Oppositional disorder was defined as a pattern of disobedient, negativistic and provocative opposition to authority figures. ${ }^{9}$ Empirical support for this nosology change was cited by the GAP's Report \#62 (1966) as only a theoretical and data-tracking mechanism.

A pattern emerged of changing diagnostic categories based upon very limited empirical knowledge but presented with positive public relations 
supporting the 'new' nosology compared with the 'old' nosology. This pattern of denigrating the past to support the future change was ongoing. The WHO and DSM-III field trials found lower than acceptable reliability and non-existent validity results for conduct disorder, yet when reviewing this new nosology they considered the change from dynamic to descriptive psychiatry a landmark in psychiatric development (Rutter and Shaffer, 1980; Sturge, Shaffer and Rutter, 1977). The much-touted DSM-III field trials included four reports of the same 24 referred youths who were diagnostically compared by one university's psychiatry department over a six-week period. Inter-rater reliability results were lower than expected for the DSM-III, and two of the reports simply described the new multi-axial system and stated it was easy to use (Cantwell, 1979; Mattison, 1979; Russell, 1979). This pattern of change continued and included: justifications and comparisons with the previous nosology (Spitzer and Cantwell, 1980); case examples from clinical practice (APA, $1991^{10}$ ); a training guide; a review of children in New Zealand (Spitzer, Williams and Skodol, 1983); public support of this new taxonomy's success, without validation (Rutter and Shaffer, 1980); and stated expectations and high confidence levels for the next upcoming DSM revisions.

The introduction of the DSM-III is the only DSM revision that provides references to the literature supporting the changes in youth behaviorallybased disorders. However, these citations do not in any empirical way further or support the nosological change. They included only: the GAP (1966) report; a study on sociopathic personality in adults (Robins, 1966); a recommendation for treatment planning (GAP, 1973); a study of biosocial factors for adult crime in Sweden (Mednick and Christiansen, 1977); and a study of child antisocial behavior correlates to adult criminal behavior (Robins, 1978).

Other clinical studies were noted in some of the APA's reference material but were not included, seemingly because the results were not significantly supportive of the change in diagnostic systems. These included a study of 225 referred cases that found conduct disorder highly prevalent, but interrater agreement moderate (alpha coefficient of 0.6) and low (alpha coefficient of 0.26 for anti-social behavior categories) (Rutter, Shaffer and Shephard, 1973), and also second-order analysis of past studies (also known as 'bootstrapping') that identified broader categories for youth disorders (Achenbach and Edelbrock, 1978). This bootstrapping methodology is highly suspect and controversial (Kirk and Kutchins, 1992).

$D S M-I I I-R$

Just seven years after the appearance of the DSM-III, the DSM-III-Revised was published. The APA justified this revision by explaining that, 'despite extensive field testing of the DSM-III diagnostic criteria before official adoption, experience with them since their publication had revealed, as 
expected, many instances in which the criteria were not entirely clear, or were even contradictory'11 (APA, 1987: xvii). Two drafts of the proposed revised diagnostic criteria were made available to interested psychiatric professionals and were distributed for review (5 Oct. 1985 and 1 Aug. 1986), and stated field trials were held for youth disruptive behavior disorders. ${ }^{12}$

The new Manual section entitled 'Disruptive Behavior Disorders' included, for the first time, both conduct disorder and oppositional defiant disorder. Conduct disorder was decreased from five to three categories, eliminating the more extreme subtypes (undersocialized aggressive, socialized aggressive; undersocialized nonaggressive, socialized nonaggressive) and adding three new subtypes (group type, solitary aggressive type, undifferentiated type). ${ }^{13}$ An assessment scale of 'mild, moderate, and severe' was now required to make a diagnosis, with no explanation for this change. Oppositional defiant disorder (with the word 'defiant' newly introduced) was expanded to meet three of five descriptor categories pulled from a shortened list of previous categories. ${ }^{14}$

Support for these significant categorization changes was claimed to be available in the DSM-III-R field trials (Spitzer, Davies and Barkley, 1990). These trials were published three years after the DSM-III-R was introduced, when the APA was well under way to publishing the next revision (DSM-IV). The trials were held at ten locations and included 550 youths who had been non-randomly referred to university psychiatry and psychology clinics. The total sample was non-representative, with three study locations that accounted for a majority of the youths. ${ }^{15} \mathrm{~A}$ clinical interview with parent and youths was used but no consistent measurement tool operationalized the $D S M-I I I-R$. The authors claimed 'the use of a large sample of children of varying ages drawn from a wide range of geographic and socioeconomic areas suggest that the results can be generalized' (Spitzer et al., 1990: 695). Reported inter-rater reliability was actually lower than that in the DSM-III field trials. Nonetheless, diagnostic changes to the $D S M-I I I-R$ were made.

Standardized measurements of the DSM diagnostic criteria increasingly showed more consistent reliability due to increased usage of a limited number of tools. Clinical studies continued to be published (though no study by the $D S M-I I I-R$ or $D S M-I V$ ), but relevance to these categorical and diagnostic system changes was still moot. Some studies were of youth from different countries or cultures (Reeves, 1987; Werry, 1983). Other studies reviewed the literature (Loeber, 1988), had lower reliability agreements than previous studies (Rey, 1988), identified parental involvement (Faraone, 1991), and correlated conduct disorder categories with later adult criminal activity (Harrington, 1991; Walker, Lahey and Russo, 1991).

\section{DSM-IV}

The Task Force on $D S M-I V$ was established in 1988. It was quickly proposed by the Task Force: that the behaviorally-based disorders for 
children and adolescents may be too narrow and restrictive; that some youth with conduct disorders will not meet the specified criteria; that the age criteria may not be appropriate; that comorbidity may be the rule rather than the exception; and that a case may need to be made for eliminating oppositional defiant disorder as a distinct entity (Shaffer, 1989). The Task Force emphasized that priorities for change included explicit documentation and evidence review (Frances, 1990). ${ }^{16}$ A specific timeline for diagnostic category review included problem formulation, literature search, cataloguing of studies, and analysis (Widiger, 1990) ${ }^{17}$ The major emphasis in preparation for $D S M-I V$ was to maximize the impact of accumulated research, utilizing data reanalysis, literature reviews and field trials. The field trials were to be surveys, videotape reliability analysis and focused field trials (Widiger, 1990). ${ }^{18}$

The APA published a precursor document intended to educate the field about potential changes. Recommended possible changes included continuing the differentiation of conduct disorder and oppositional defiant disorder or conceptualizing both within one category, disruptive behavior disorder. This would include three levels: oppositional defiant type; moderate conduct type; and severe conduct type. These decisions were dependent on the field trials and data reanalysis outcomes (APA, 1991). The precursor document was followed by a DSM-IV Draft Criteria (APA, 1993) which increased the conduct disorder diagnostic criteria from thirteen to fifteen ${ }^{19}$ and made one criterion change to oppositional defiant disorder. ${ }^{20} \mathrm{~A}$ third category, 'disruptive behavior disorder not otherwise specified', was added for disorders characterized by these two other disorders but not meeting the criteria (APA, 1993).

The DSM-IV was introduced in 1994 through the claimed support of 13 work groups reporting to 27 task force members and up to 100 advisors (APA, 1994). Individual work groups co-ordinated the literature reviews, data reanalysis and field trials. The results were to be printed in a 5-volume DSM-IV Sourcebook, but these were not all available until 1997 (Widiger, Francis, Pincus, et al., 1992, 1994, 1996, 1997). The conduct disorder diagnosis was printed exactly as recommended in the draft version (APA, 1993). The time frame for criteria was extended from 6 to 12 months and further specified by a child or adolescent onset category with a minimum age of 10 required (APA, 1994: 90-1). The oppositional defiant diagnosis was printed exactly as recommended in the draft version. The 'disruptive behavior disorder not otherwise specified' was included as a third psychiatric diagnosis.

This pattern of changing diagnostic categories and disorders based upon very limited (or even contradictory) knowledge, but presented with positive public relations supporting the 'new' nosology, continued. Published empirical support for the DSM-IV diagnostic changes was limited at best. In a review of existing literature (Loeber, Lahey and Thomas, 1991), conduct 
and oppositional defiant disorders were found to be very developmentally related but clearly distinct. However, this review failed to detail adequately the analysis method to support this claim. The DSM-IV Options Book (APA, 1991) cited only this review of literature in making recommendations for change. The discussion of combining the behavioral-based disorders or continuing the existing hierarchy relied on one published review (Quay, 1986) and two unpublished reviews (see Lahey, Loeber and Quay, 1992). ${ }^{21}$ In claiming support for the conduct disorder severity level change, there emerged a pattern of citing unpublished studies (in this case, one by Loeber and two by Rogeness).

The DSM-IV Sourcebook, Vol. 3, encapsulated all reported new data and methodology for childhood and adolescent disorders (Widiger et al., 1996); the literature reviews, data reanalysis and research studies from the period covered (1992-96) included only two new clinical studies supporting the change in either conduct or oppositional defiant disorders (Lahey et al., 1992; Loeber, 1993). ${ }^{22}$ The first study offered no new clinical data, while the second introduced three levels of developmental severity and found confirmatory results. The field trials for these two disorders, released in August 1994 (Lahey, 1994), ${ }^{23}$ found similar reliability to that of DSM-III-R and claimed improved construct validity using the DISC-2 to examine 440 referred youths. The iterative multiple bootstrapping analysis technique used has been criticized as methodologically suspect (Kirk and Kutchins, 1992), although the field trial authors claim credibility in making the recommended changes to the diagnostic categories (Waldman and Lahey, 1994). The authors claimed an additional finding, the use of one disorder criterion to be used in diagnosing another behavior disorder, but declined to incorporate this recommendation due to causing practitioner confusion. 'Success' was claimed. ${ }^{24}$ Some of these same field trial authors later disputed this claimed 'success', identifying the methodological shortcomings of the studies and their failure to reach empirically valid plateaus (Lahey, McBurnett and Loeber, 1994).

The references cited in the field trials included: reiterations of past studies already critiqued (Lahey, 1990; Loeber, 1990, 1993; Robins and Price, 1991); two diagnostic measurement tools (Setterbert, 1992; Shaffer, 1992); unpublished data by Hart (Sourcebook,Vol. 1; Widiger et al., 1992); and epidemiology studies of youth in Puerto Rico (Bird, 1990, 1992). The final Sourcebook (Vol. 4, which by the time of publication included both Vols 4 and 5) was released by the APA in 1997 and, ironically, concluded that changes in the behaviorally-based disorders from $D S M-I I I-R$ were unnecessary, except for the addition of a few new descriptive symptoms (Widiger et al., 1997).

\section{Key individuals}

In my analyses of published and unpublished literature and of committee, task force and work group memberships, eight individuals emerged as 
excessively influential in the DSM nosology changes and definitions of youth behaviorally-based disorders in this period (see Table 2). Thomas Achenbach's work on behavioral checklists is referentially admired; however, his personal opinion differs substantially from that of his supporters. He is sceptical of the changes to these disorders over time, thinks that the DSM revisions became a commercial and not an empirical process, and that the Manual reflects the political and research interests of the authors (the APA). This committee member believed at the time that the work generated from the APA committees he served on was never used in the decision-making process and is presumed to still be 'in Robert Spitzer's office'. ${ }^{25}$

Michael Rutter's preliminary proposal for a multi-axial system was the foundation for the DSM change from a dynamic to a descriptive psychiatric nosology. David Shaffer, co-author with Michael Rutter of this multi-axial classification system, was an influential member of five committees, and co-

TABLE 2. Key individuals in the period 1969-2000

\begin{tabular}{lccl}
\hline & Citations $^{\text {a }}$ & Publications $^{\mathrm{b}}$ & $\begin{array}{l}\text { Committees/task forces/work } \\
\text { groups }^{\text {c }}\end{array}$ \\
\hline Thomas Achenbach & 28 & 2 & F G H \\
David Shaffer & 22 & 6 & D F G I J (co-Chair) \\
Robert Spitzer & 16 & 5 & A C (Chair) E (Chair) F G I \\
Dennis Cantwell & 12 & 1 & C D E F G I J \\
Benjamin Lahey & 8 & 10 & J K L \\
Rolf Loeber & 6 & 9 & J K L \\
Janet Williams & 6 & 1 & E F G I \\
Michael Rutter & & 2 & J L \\
\hline
\end{tabular}

a Number of citations from published sources (DSM nosology).

b This tally includes the number of publications by each author that were part of the material used by the APA as research supporting the changes to the DSM (III through IV). In total, 127 possible publications were referenced by the APA during this period.

c A. Committee on Nomenclature and Statistics (1972-75)

C. Task Force on Nomenclature and Statistics (1975-79)

D. Committee for Infancy, Childhood, and Adolescent Disorders (1977-79)

E. Work Group to Revise DSM-III (1977-79)

F. Committee for Infancy, Childhood, and Adolescent Disorders (1983-86)

G. Subcommittee on Disruptive Behavior Disorders (1985-87)

H. DSM-III-R Field Trial Participants (1986)

I. Task Force on DSM-IV (1988-94)

J. Work Group for Infancy, Childhood, and Adolescent Disorders (1992-94)

K. Disruptive Behavior Disorders Field Trials (1993-96)

L. DSM-IV Data Reanalysis Project for Childhood and Adolesence (1997) 
chaired one committee. Shaffer believes that earlier DSM versions and behaviorally-based disorders were appropriately maligned for political reasons; however, the $D S M-I V$ raised the credibility of the diagnostic system through the 'rigors of science'. ${ }^{26}$

Benjamin Lahey's influence was on the $D S M-I V$ revision committees ${ }^{27}$ and as author of the Sourcebook (Vol. 3) literature review of conduct and oppositional defiant disorders. Lahey believes his work assisted in reaching more reliable recommendations, but has concerns that the lower thresholds of the behaviorally-based disorders for youth are arbitrary. He is very concerned that the APA's monopoly powers lead to myopic views and decision-making and recommends a larger body, the World Health Organization, to emulate this systemic review. ${ }^{28}$ Dennis Cantwell was a member of all significant task force and committees, except one. ${ }^{29}$

Robert Spitzer was the most influential person driving these nosology changes and definitions. As a long-time consultant for the APA beginning in the early 1970 s, Spitzer chaired the two most powerful committees recommending this change from dynamic to descriptive psychiatry ${ }^{30}$ and served on four additional committees. Spitzer authored the DSM-III-R field trials for childhood disruptive behavioral diagnosis (Spitzer et al., 1994), the DSM-III Casebook (Spitzer, First, Gibbon, Skodol, et al., 1989), and the DSM-III-R Casebook (Perry, Francis and Clarkin, 1990); and introduced the controversial use of the kappa coefficient to support DSM nosology system reliability. It is Spitzer's belief that the DSM-III and later revisions have moved psychiatry away from art and become a science through increased data-based decisions and descriptive methodology, leading to the field's increased ability to study causality. ${ }^{31}$

\section{Exponential individual influence}

To be involved in the decision-making committee work, an individual was regarded as an expert within a certain psychiatric disorder field and received an invitation directly from the APA. However, these invitations were somewhat arbitrary, had more to do with institutional reputation and networking and, more often than not, occurred after consultation with Robert Spitzer. This group of inordinately influential individuals was of two distinct perspectives regarding the $D S M$ nosology change process with which they were involved. The first group of individuals who saw this change as a step forward were closely aligned with the APA (Shaffer, Spitzer and Williams), while the others who are critical of these changes were psychiatrists and psychologists not closely aligned with the APA (Lahey, Loeber and Achenbach). Spitzer came to his position of power based on his early published graduate school research on youth disorders and the inordinate attention this brought from him the APA during a period when the Association was announcing the need to expand childhood and adolescent disorders (DSM-II, 1968 to DSM-III, 1980). Shaffer and Williams (Spitzer's wife) 
worked together for many years at the Biometrics Research Department at New York State Psychiatric Institute and at Columbia University during their pivotal leadership roles with the APA decision-making committees.

\section{Social construction of behaviorally-based disorders}

This review identifies the historical development of youth psychiatric nosology systems and behaviorally-based disorders within a socially constructed framework. The earlier methodical changes (1880-1968) and more recent exponential expansion (1969-2000) of these youth psychiatric disorders, without any clear empirical support, is testimony to the excessive influence of noted individuals and the American Psychiatric Association. This small cadre was very successful over time in presenting what looked like a thorough, inclusive process of change, although the aetiology was actually propelled forward by rhetoric and promises, but it was receptively received by a very biologically-determinative medical community and lay public. The mental health field was burgeoning, market share was available, and the American Psychiatric Association (and psychiatric field) stepped forward with answers presented as truth.

\section{Notes}

1. US spelling of 'behavior' is retained throughout this paper.

2. A revision of the Standard Nomenclature of Diseases and Pathological Conditions, Injuries, and Poisonings for the United States (U.S. Census Bureau, 1910).

3. This included the American College of Surgeons, American Heart Association, American Hospital Association, American Statistical Association, American Surgical Association, Association of American Physicians, several New York hospital systems, U.S. Census Bureau, U.S. Public Health Service and medical departments for the Army and Navy.

4. The Academy of Psychiatry and Law, the American Academy of Child Psychiatry, the American Academy of Psychoanalysis, the American Association of Chairmen of Departments of Psychiatry, the American College Health Association, the American Orthopsychiatric Association, the American Psychoanalytic Association and the American Psychological Association.

5. A failure to establish a normal degree of affection, empathy, or bond with others' (DSMIII; APA, 1980: 45).

6. 'Evidence of social attachment to others and the violation of the rights of others through aggressive acts' (DSM-III; APA, 1980: 45).

7. 'Characterized by a repetitive and persistent pattern of non-aggressive conduct in which either the basic rights of others or major age-appropriate societal norms or rules are violated' (DSM-III; APA, 1980: 48).

8. 'A residual category for illnesses involving a pattern of conduct in which there is violation of either the basic rights of others or major age-appropriate societal norms or rules which cannot be classified as an other subtype' (DSM-III; APA, 1980: 50).

9. 'Appropriate for a child three to eighteen years of age who is oppositional to a family member or teacher, persistently even when this behavior is against the interests of the child' (DSM-III; APA, 1980: 63). 
10. Of the 200 case examples reported to come from practice, only three were for youth (two for socialized aggressive conduct disorder; one for under-socialized conduct disorder).

11. Most of the recommendations for change came from the numerous advisory committees formed and organized through the APA. These committees were assigned one specific diagnosis each for further review.

12. Appendix F of the DSM-III-R stated only that 550 youths were assessed and cited the locations of review. These results were not published until 1990.

13. The disorder still needed a six-month time frame and required at least three of the following: 'stealing without confrontation of the victim on more than one occasion; run away from home overnight at least twice; often lies; has deliberately engaged in firesetting; is often truant from school; has broken into someone else's house; has deliberately destroyed others' property; physical cruelty to animals; forced someone into sexual activity; used weapons in more than one fight; stole with confrontation of a victim; or has been physically cruel to people' (DSM-III-R; APA, 1987: 58).

14. Categories included: often loses temper; argues with adults; often actively defies or refuses adult requests; often deliberately does things that annoy others; often blames others for mistakes; often touchy or easily annoyed by others; often angry and resentful; often spiteful or vindictive or often swears (DSM-III-R; APA, 1987: 60).

15. These locations were at the Loeber's, Shaffer's and Spitzer's employment institutes.

16. 'The threshold for making revisions is much higher than it was for DSM-III and DSM-III$R$. Decisions must be substantiated by explicit statements of rationale and by systemic review of relevant empirical data ... placement in the DSM should not determine whether or not a disorder is studied and researched ... but for the DSM-IV to have credibility as a system of diagnosis, its clinic uses and foundation in research must have priority' (Frances, 1990: 1441-2).

17. It was anticipated 'that in some cases a comprehensive review of available data will fail to identify a sufficient amount of supportive research to justify a revision' (Widiger, 1990: 198).

18. The opinion surveys were to be focused on clinicians in the field who had utilized interrater reliability as a measure of usefulness of the Manual. The field trials were to present reliability and validity data for proposed revisions, including disruptive behavior disorders for children.

19. With the addition of 'often bullies, threatens, or intimidates others' and 'often stays out at night despite parental prohibitions, beginning before thirteen years of age' (APA, 1993: 10).

20. Not including 'often swears or uses obscene language' as a diagnostic criterion (APA, 1993: 10).

21. Even so, the authors later claimed these disorders may 'be related both hierarchically and developmentally' (Lahey et al., 1992: 541).

22. Three options within the literature for diagnostic changes were reviewed: to continue the $D S M-I I I-R$ categories without change; to retain these categories with criteria changes if supported by data from the DSM-IV Field Trials; or to eliminate the distinction between these two categories and consider them as developmentally staged levels of one disorder. 'This review is based on relevant literature accessed using a combination of computer searches and reference to personal libraries.' (Lahey et al., 1994: 191). The details of this methodology were not reported.

23. There was a pre-release article trumping the upcoming release, giving some highlights and methodology, marketing the analysis technique used and claiming success in the findings (Waldman and Lahey, 1994). An additional pre-release study discussed the field trials 
utility estimates, citing the confirmatory iterative bootstrapping strategy, relying on positive predictive power and negative predictive power to guide diagnostic criteria development. 'PPN is the proportion of individuals with the symptoms who have the disorder; NPP is the conditional probability of the disorder being absent given the absence of the symptom.' (Frick, 1994: 530). This was claimed to have allowed for the inclusion of 'lying' and 'truancy' in conduct disorder criteria and eliminating 'swearing' in oppositional defiant disorder criteria.

24. The regression analysis data were not published; reportedly these can be requested from the author (Lahey). ' $D S M-I V$ definitions of oppositional defiant disorder and conduct disorder are somewhat better than DSM-III-R definitions in terms of internal consistency and test-retest agreement, and the validity of the $D S M-I V$ definition of oppositional defiant disorder is slightly better than that of DSM-III-R.' (Lahey, 1994: 1163).

25. Interview with Thomas Achenbach (28 Feb. 1999).

26. Interview with David Shaffer (29 Mar. 1999).

27. Work group for Infancy, Childhood, and Adolescent Disorders; Disruptive Behavior Disorders Field Trials; and DSM-IV Data Reanalysis Project for Childhood and Adolescence.

28. Interview with Benjamin Lahey (2 Mar. 1999).

29. Dennis Cantwell, Luton Ackerson and Richard Jenkins were deceased at the time of this research.

30. The Task Force on Nomenclature and Statistics; and Work Group to Revise DSM-III.

31. Interview with Robert Spitzer (24 Feb. 1999).

\section{References}

Achenbach, T. and Edelbrock, C. (1978) The classification of child psychopathology: a review and analysis of empirical efforts. Psychological Bulletin, 85(6), 1275-301.

Ackerman, N. W. (1953) (Chapter 3). In P. M. Hoch and J. Zubin (eds), Current Problems in Psychiatric Diagnosis (New York: Grune and Stratton, Inc.), 87-104.

Ackerson, L. (1932) Children's Behavior Problems (Chicago: University of Chicago Press, Behavior Research Fund Monograph).

Ackerson, L. (1942) Children's Behavior Problems, 2nd edn (Chicago: University of Chicago Press, Behavior Research Fund Monograph).

APA (1952, 1968, 1980, 1987, 1994) Diagnostic and Statistical Manual of Mental Disorders, DSM-I, -II, -III, -III-R, -IV (Washington, DC: American Psychiatric Association).

APA (1991) Work in Progress: DSM-IV Options Book (Washington, DC: American Psychiatric Association).

APA (1993) DSM-IV Draft Criteria (Washington, DC: American Psychiatric Association).

Atkins, D., Pumariega, A., Rogers, K., Montgomery, L., Nybro, C., Jeffers, G. and Sease, F. (1999) Mental health and incarcerated youth. I: Prevalence and nature of psychopathology. Fournal of Child and Family Studies, 8(2), 193-204.

Barzun, J. and Graff, H. (1987) The Modern Researcher (New York: Harcourt Brace Jovanovich).

Beller, E. K. (1962) Clinical Process: A New Approach to the Organization and Assessment of Clinical Data (Glencoe, IL: The Free Press).

Berndt, D., Ellmer, R.M., Toprac, M.G., Rouse, L.W., Mason, M. and MacCabe, N. (1995) Mental health service utilization by clusters of children with serious emotional disturbance. In K. Kutash and C. Liberton (eds), Seventh Annual Research Conference 
Proceedings, a System of Care for Children's Mental Health: Expanding the Research Base (Tampa: University of South Florida, Florida Mental Health Institute), 3-8.

Berrios, G. (1996) The History of Mental Symptoms (Cambridge: Cambridge University Press).

Bird, H. R. (1990) Impairment in the epidemiological measurement of childhood psychopathology in the community. Fournal of the American Academy of Child and Adolescent Psychiatry, 29, 796-803.

Bird, H. R. (1992) Aggregating data from multiple informants in child psychiatry epidemiological research. Fournal of the American Academy of Child and Adolescent Psychiatry, 31, 78-85.

Brown, Potter, Pollack, and Cohen Classification System (New York: New York State Hospital Association, 1937).

Buckner, J. C. and Bassuk, E. L. (1997) Mental disorders and service utilization among youths from homeless and low-income housed families. Fournal of the American Academy of Child and Adolescent Psychiatry, 36(7), 890-900.

Bukstein, O. B., Brent, D. A. and Kaminer, Y. (1989) Comorbidity of substance abuse and other psychiatric disorders in adolescents. American fournal of Psychiatry, 146, 1131-41.

Burt, G. (1937) Study of Troubled Children (New York: Columbia University Institute Press).

Cameron, K. (1955) Diagnostic categories in child psychiatry. British fournal of Medicine and Psychology, 28, 67-71.

Cantwell, D. (1979) A comparison of DSM-II and DSM-III in the diagnosis of childhood psychiatric disorders (IV). Archives of General Psychiatry, 36, 1227-32.

Caplan, P. (1995) They Say You're Crazy (Reading, MA: Addison-Wesley).

Carr, E. H. (1961) What is History? (London: MacMillan).

Chapman, J. C. and Counts, G. S. (1924) Principles of Secondary Education (Houghton Mifflin: Boston Publishing).

Chess, S. (1959) An Introduction to Child Psychiatry (New York: Grune and Stratton).

Church, R. (1976) Education in the United States: An Interpretive History (New York: The Free Press).

Cohen, P. (1993) An epidemiological study of disorders in late childhood and adolescence - I. Age and gender specific prevalence. II [with Cohen, J. and Brook, J.]. Persistence of disorders. Fournal of Child Psychology and Psychiatry, 34(6), 869-77.

Cooper, R. (2004) What is wrong with the DSM? History of Psychiatry, 15(1), 5-25.

Costello, E. (1985) Validity of the NIMH diagnostic interview schedule for children: a comparison between psychiatric and pediatric referrals. Fournal of Abnormal and Child Psychology, 13(4), 579-95.

Costello, E., Angold, A., Burns, J. G., Stangl, D. K., Tweed, D. L. Erkanli, A. and Worthman, C. M. (1996) The Great Smoky Mountains study of youth: goals, design, methods, and the prevalence of DSM-III-R disorders. Archives of General Psychiatry, 53, 1129-36.

Davis, D. L., Bean., G. J., Schumacher, J. E. and Stringer, T. L. (1991) Prevalence of emotional disorders in a juvenile justice institutional population. American fournal of Forensic Psychology, 9, 1-13.

Davoli, C. R. and Stock, H. (1982) Report of the Task Force on the Mentally Ill Adolescent Offender (Lansing, MI: Departments of Management and Budget, Mental Health, and Social Services).

DeMilio, L. (1989) Psychiatric syndromes in adolescent substance abusers. Fournal of the American Academy of Child and Adolescent Psychiatry, 146(10), 1212-14.

Diagnostic Classification in Child Psychiatry (APA Report \#18) (Washington, DC: American Psychiatric Association, 1964). 
Dreger, R. (1964) Behavioral classification project. Fournal of Consulting Psychology, 28(1), 1-13. Dumont, M. (1984) The nonspecificity of mental illness. American fournal of Orthopsychiatry, $4(2), 325-34$.

Faraone, S. V. (1991) Separation of DSM-III attention deficit disorder and conduct disorder: evidence from a family genetic study of American child psychiatry patients. Psychological Medicine, 21(4), 109-21.

Fleck, L. (1935) Genesis and Development of a Scientific Fact (Chicago and London: The University of Chicago Press).

Frances, A. (1990) DSM-IV: work in progress. American fournal of Psychiatry, 147, 1439-48.

Frank, R. and Manning, W. (1992) Economics and Mental Health (Baltimore, MD: Johns Hopkins University Press).

Freud, S. (1905) Three essays on the theory of sexuality. In The Standard Edition of the Complete Psychological Works of Sigmund Freud, Vol. 7, ed. and trans. by J. Strachey et al. (London: Hogarth Press, 1924-1934), 130-243.

Frick, P. (1994) DSM-IV field trials for disruptive behavior disorders: symptom utility estimates. Fournal of the American Academy of Child and Adolescent Psychiatry, 33(4), 529-39.

GAP, Committee on Child Psychiatry (1957) The Diagnostic Process in Child Psychiatry (Report \#38) (New York: APA Press).

GAP (1966) Psychopathological Disorders in Childhood: Theoretical Considerations and Proposed Classification (Report \#62) (New York: APA Press).

GAP (1973) From Diagnosis to Treatment: An Approach to Treatment Planning for the Emotionally Disturbed Child. Report \#87 (New York: Group for the Advancement of Psychiatry, Publications Office).

Garland, A., Hough, R. L., McCabe, K. M., Yeh, M., Wood, P. and Aarons, G. A. (2001) Prevalence of psychiatric disorders in youths across five sectors of care. Fournal of the American Academy of Child and Adolescent Psychiatry, 40(4), 409-26.

Greenbaum, P., Prange, M., Friedman, R. and Starr, S. (1991) Substance abuse prevalence and comorbidity with other psychiatric disorders among adolescents with severe emotional disturbances. Fournal of the American Academy of Child and Adolescent Psychiatry, 30(4), 575-83.

Grob, G. (1994) The Mad Among Us: A History of the Care of America's Mentally Ill (New York: The Free Press).

Halikas, J. A., Meller, J., Morse, C. and Lyttle, M. D. (1990) Predicting substance abuse in juvenile offenders: attention deficit disorder vs. aggressivity. Child Psychiatry and Human Development, 21, 49-55.

Hall, G. (1893) The Contents of Children's Minds on Entering School (New York: Kellogg).

Hall, G. (1904) Adolescence, its Psychology (New York: D. Appleton and Co.).

Hall, R. (1948) Patterns of Abnormal Behavior (New York: Allyn \& Bacon).

Harrington, R. (1991) Adult outcomes of childhood and adolescent depression. II: Links with antisocial disorders. Fournal of the American Academy of Child and Adolescent Psychiatry, 30, 434-9.

Hewitt, E. and Jenkins, R. (1946) Fundamental Patterns of Maladjustment - The Dynamics of their Origin (Ann Arbor, MI: University of Michigan Press).

Hollander, H. E. and Turner, F. D. (1985) Characteristics of incarcerated delinquents: relationships between development disorders, environmental and family factors, and patterns of offense and recidivism. Fournal of the American Academy of Child Psychiatry, 24, 221-6. 
Hutt, M. L. and Gibby, R. (1957) Patterns of Abnormal Behavior (Boston: Allyn and Bacon).

Jenkins, R. (1964) The varieties of children's behavioral problems and family dynamics. American fournal of Psychiatry, 124(10), 1440-5.

Jenkins, R. and Hewitt, L. (1944) Types of personality structure encountered in child guidance clinics. American fournal of Orthopsychiatry, 14(1), 84-94.

Jenson, R. A. (1959) Child psychiatry. In I. McQuarrie (ed.), Brenneman's Practice of Pediatrics (Hagerston, MD: W. F. Prior).

Kanner, L. (1935) Child Psychiatry (Springfield, IL: Charles C. Thomas).

Kashani, J. H. (1987) Psychiatric disorders in a community sample of adolescents. American Fournal of Psychiatry, 144(5), 584-9.

Kett, J. F. (1977) Rites of Passage: Adolescence in America, 1790 to the Present (New York: Basic Books).

Kirk, S. A. and Kutchins, H. (1986) The reliability of DSM-III: a critical review. Social Work, $23,3-11$.

Kirk, S. A. and Kutchins, H. (1992) The Selling of the DSM (New York: Aldine De Gruyter Press).

Krathwohl, D. (1992) Methods of Educational and Social Science Research (New York: Longman, Inc.).

Lahey, B. (1990) Comparison of DSM-III and DSM-III-R diagnoses for prepubertal children: changes in prevalence and validity. Fournal of the American Academy of Child and Adolescent Psychiatry, 29, 620-6.

Lahey, B. (1994) DSM-IV field trials for oppositional defiant disorder and conduct disorder in children and adolescents. American fournal of Psychiatry, 151(8), 1163-71.

Lahey, B., Loeber, R. and Quay, H. C. (1992) Oppositional defiant and conduct disorders: issues to be resolved for DSM-IV. Fournal of the American Academy of Child and Adolescent Psychiatry, 31, 539-46.

Lahey, B., McBurnett, K. and Loeber, R. (1994) Psychobiology of conduct disorder. In G. P. Sholevar (ed.), Conduct Disorders in Children and Adolescents: Assessment and Interventions (Washington DC: American Psychiatric Press), 324.

Loeber, R. (1988) Natural histories of conduct problems, delinquency and associated substance abuse: Evidence for developmental progressions. In B. Lahey and A. Kazdin (eds), Advances in Clinical Child Psychology, Vol. 11 (New York: Plenum Press).

Loeber, R. (1990) Mental health professional's perception of the utility of children, mothers, and teachers as informants on childhood psychopathology. Fournal of Clinical Child Psychology, 19(2), 136-43.

Loeber, R. (1993) Evidence for developmentally based diagnoses of oppositional defiant disorder and conduct disorder. Fournal of Abnormal Child Psychology, 21 (4), 377-410.

Loeber, R., Lahey, B. and Thomas, C. (1991) Diagnostic conundrum of oppositional defiant disorder and conduct disorder. Fournal of Abnormal Psychology, 100(3), 379-90.

Logie, H. B. (1933) Standard Classified Nomenclature of Disease (Brattleboro, VT: E. L. Hildreth and Co.).

Malinowski, B. (1954) Magic, Science and Religion (New York: Doubleday Anchor Books).

Marsteller, F., Brogan, D. and Smith, I. (1997) The prevalence of substance use disorders among juveniles admitted to regional youth detention centers operated by the Georgia Department of Children and Youth Services. Council on Substance Abuse Treatment, Final Report to the Governor (unpublished)

Mattison, R. (1979) A comparison of DSM-II and DSM-III in the diagnosis of childhood psychiatric disorders: II. Interrater agreement. Archives of General Psychiatry, 36, 1217-22. 
McCarthy, T. (1978) The Critical Theory of furgen Habermas (Cambridge, MA.: MIT Press).

McGarvey, E. and Waite, D. (2000) Mental Health Needs among Adolescents Committed to the Virginia Department of Fuvenile Fustice. Retrieved 1 Oct. 2004 from Virginia Department of Criminal Justice website: http://www.ilppp.virginia.edu/Publications_and_Reports/ MNHeedsAdol.html.

McManus, M., Alessi, N. E., Grapentine, W. L. and Brickman, A. S. (1984) Psychiatric disturbance in serious delinquents. Fournal of the American Academy of Child Psychiatry, 23, 602-15.

McPherson, P. (1991) Unpublished data, Department of Psychiatry, Case Western Reserve University.

Mechanic, D. (1999) Mental Health and Social Policy: The Emergence of Managed Care, 4th edn (Needham Heights, MA: Allyn and Bacon).

Mednick, S. and Christiansen, K. (1977) Biosocial Bases of Criminal Behavior (New York: Gardner Press, Inc.).

Milin, R., Halika, J. A., Meller, J. E. and Morse, C. (1991) Psychopathology among substance abusing juvenile offenders. Fournal of the American Academy of Child and Adolescent Psychiatry, 30, 569-74.

NCFCJ (2004) Tennessee's Youth in Fuvenile Fustice Facilities: Mental Health, Substance Abuse and Developmental Disability Issues. Retrieved 20 Sept. 2004 from: http://www.state.tn.us/ mental/cj/jimhreport061104.pdf.

Neubauer, J. (1992) The Fin-de-siècle Culture of Adolescence (New Haven: Yale University Press).

New York Medico-Legal Society (1886) International Committee on International Statistics of the Insane and Classification of Mental Diseases (New York: New York Medico-Legal Society).

Office of Juvenile Justice and Delinquency Prevention (August, 2004) Assessing the mental health status of youth in juvenile justice settings. Retrieved 30 Sept. 2004) from: http://www.ojp.usdoj.gov/ojidp.

Pacella Classification System (Chicago, IL: American Medical Association, 1948).

Pearson Nosology (Oxford: Oxford University Research System, 1920).

Pearson, G. H. (1949) Emotional Disorders of Children (New York: W. W. Norton, Inc.).

Perry, S., Francis, A. and Clarkin, J. (1990) A DSM-IIIR Casebook of Treatment Selection (New York: Brunner/Mazel).

Platt, A. (1969) The Child Savers: The Invention of Delinquency (Chicago: Chicago University Press).

Plunkett, R. and Hayden, A. (1952) Standard Nomenclature of Disease and Operations, 4th edn (New York: The Blakiston Company).

Policy Design Team (1994) Mental Health Needs of Youth in Virginia's fuvenile Detention Centers (Richmond, VA: Department of Criminal Justice Services).

Poster, M. (1989) Critical Theory and Poststructuralism (Ithaca, NY: Cornell University Press).

Pottick, K., Warner, L., Isaacs, M., Henderson, M., Milazzo-Sayre, C. and Manderscheid, R. (2002) Children and adolescents admitted to specialty mental health care programs in the United States, 1986 and 1997. In R. W. Manderscheid and M. A. Sondheimer (eds), Mental Health, United States, 2002 (Washington DC: U.S. Government Printing Office), Chapter 20.

Quay, H. (1986) Dimensions of personality in delinquent boys as inferred from the factor analysis of case history data. Child Development, 35, 479-84.

Reeves, R. (1987) Attention deficit, conduct, oppositional, and anxiety disorders in children: II. Clinical characteristics. Fournal of the American Academy of Child and Adolescent Psychiatry, 26(2), 144-55. 
Restivo, S. and Loughlin, J. (1987) Critical sociology of science and scientific validity. Knowledge: Creation, Diffusion, Utilization. March, 8(3), 486-508.

Rey, J. (1988) Oppositional disorder: fact or fiction. Fournal of the American Academy of Child and Adolescent Psychiatry, 27(2), 157-62.

Robins, L. (1966) Defiant Children Grown Up (Baltimore: The Williams and Wilkins Company).

Robins, L. (1978) Sturdy childhood predictors of adult antisocial behavior: replications from longitudinal studies. Psychological Medicine, 8, 611-22.

Robins, L. and Price, R. K. (1991) Adult disorders predicted by childhood conduct problems: results from the NIMH epidemiologic catchment area project. Psychiatry, 54, 116-33.

Rose, J. A. (1958) The emotional problems of children. In Psychiatry for the General Practitioner (Philadelphia, PA: Philadelphia Mental Health Educational Unit of Smith, Kline and French Laboratories).

Rosenblatt, A. (1992) Integrating systems of care in California for youth with severe emotional disturbance. I: A descriptive overview of the California AB377 evaluation project. Fournal of Child and Family Studies, 1(1), 93-113.

Rubin, A. and Babbie, E. (2000) Research Methods for Social Work (New York: Brooks/Cole Publishing).

Russell, A. (1979) A comparison of DSM-II and DSM-III in the diagnosis of childhood psychiatric disorders (III). Archives of General Psychiatry, 36, 1223-6.

Rutter, M. (1969) A tri-axial classification of mental disorders in childhood, an international study. Fournal of Child Psychology and Psychiatry, 10, 41-61.

Rutter, M. and Shaffer, D. (1980) DSM-III: a step forward or back in terms of the classification of child psychiatric disorders. Fournal of the American Academy of Child Psychiatry, 19, 371-94.

Rutter, M., Shaffer, D. and Shephard, M. (1973) An evaluation of the proposal for a multiaxial classification of child psychiatric disorders. Psychological Medicine, 3, 244-50.

Selbach, H. (1960) Cited by: E. Stengel (1964) Classification of mental disorders. Bulletin of the World Health Organization, 21, 601-33.

Setterbert, S. (1992) Parent and Interview Version of the Children's Global Assessment Scale (New York: Columbia University).

Shaffer, D. (1989) Child and adolescent psychiatric disorders in DSM-IV: issues facing the work group. Fournal of the American Academy of Child and Adolescent Psychiatry, 28, 830-5.

Shaffer, D. (1992) NIMH Diagnostic Interview Schedule for Children, Version 2.3 (New York: Columbia University).

Shaffer, D. (1996) The NIMH diagnostic interview schedule for children version 2.3 (DISC2.3): description, acceptability, prevalence rates, and performance in the MECA study. Fournal of the American Academy of Child and Adolescent Psychiatry, 35, 865-77.

Shelton, D. (1998) Estimates of emotional disorder in detained and committed youth in the Maryland juvenile justice system. Unpublished report to the Maryland Juvenile Justice Advisory Council.

Silver, S. E., Duchnowski, A. J., Kutash, K., Friedman, R. M., Eisen, M., Prange, M. E., et al. (1992) A comparison of children with serious emotional disturbance served in residential and school settings. Fournal of Child and Family Studies, 1, 43-59.

Spitzer, R. and Cantwell, D. (1980) The DSM-III classification of the psychiatric disorders of infancy, childhood and adolescence. Fournal of the American Academy of Child Psychiatry, 19, 356-70.

Spitzer, R., Davies, M. and Barkley, R. (1990) The DSM-III-R field trials of disruptive behavior disorders. Fournal of the American Academy of Child and Adolescent Psychiatry, 29(5), 690-7. 
Spitzer, R., First, M., Gibbon, M., Skodol, A. and Williams, J. (1989) DSM-III Casebook (Boston, MA: Cambridge University Press).

Spitzer, R., Williams, J. and Skodol, A. (1983) International Perspectives on DSM-III (Washington, DC: American Psychiatric Press).

Standard Classified Nomenclature of Diseases and Pathological Conditions, Injuries, and Poisonings for the United States, 3rd, 4th edns (Washington DC: American Psychiatric Association, 1950, 1956).

Standard Nomenclature of Diseases, 1st, 2nd, 3rd, 4th, 5th edns (Boston, MA: Northeast Hospital Consortium, 1933-1961).

Statistical Manual for the Use of Institutions for the Insane (Chicago, IL: Association of Medical Superintendents of American Institutions for the Insane, 1917).

Stowell, R. J. A. and Estroff, T. W. (1992) Psychiatric disorders in substance-abusing adolescent inpatients: a pilot study. Fournal of the American Academy of Child and Adolescent Psychiatry, 31, 1036-40.

Sturge, C., Shaffer, D. and Rutter, M. (1977) The reliability of diagnostic categories for child psychiatric disorders in ICD-9. Paper read at the Royal College of Psychiatrists Section of Child Psychiatry Meeting, Stirling, Scotland, 1976.

Szasz, T. (1994) Mental illness is still a myth. Society, (May/June), 34-9.

Teplin, L. A., Abram, K., McClelland, G., Dulcan, M. and Mericle, A. (2002) Psychiatric disorders in youth in juvenile detention. Archives of General Psychiatry, 59, 1133-43.

Timmons-Mitchell, J., Brown, C., Schulz, C., Webster, S., Underwood, L. and Semple, W. (1997) Comparing the mental health needs of female and male incarcerated juvenile delinquents. Behavioral Sciences and the Law, 15, 195-202.

U.S. Census Bureau (1910) Standard Nomenclature of Diseases and Pathological Conditions, Injuries, and Poisonings for the United States (Washington DC: U.S. Census Bureau).

U.S. Census Bureau (1918-1942) The Statistical Manual for the Use of Hospitals for Mental Diseases, 10 editions (Washington DC: U.S. Government Printing Office).

van Praag, H. M. (1993) “Make-believes” in Psychiatry (New York: Brunner/Mazel).

Velez, C., Johnson, J. and Cohen, P. (1989) A longitudinal analysis of selected risk factors for childhood psychopathology. Fournal of the American Academy of Child and Adolescent Psychiatry, 28(6), 861-4.

Waldman, I. and Lahey, B. (1994) Design of the DSM-IV disruptive behavior disorder field trials. Child and Adolescent Psychiatric Clinics of North America, 3(2), 195-208.

Walker, J. L., Lahey, B. and Russo, M. (1991) Anxiety, inhibition, and conduct disorder in children. I: Relations to social impairment. Fournal of the American Academy of Child and Adolescent Psychiatry, 30, 187-91.

Werry, J. (1983) The interrater reliability of DSM-III in children. Fournal of Abnormal Child Psychology, 11(3), 341-54.

WHO [World Health Organization] (1957, 1965) Manual of the International Statistical Classification of Diseases, Injuries, and Causes of Death (New York: United Nations).

Widiger, T. (1990) DSM-IV literature reviews: rationale, process and limitations. Fournal of Psychopathology and Behavioral Assessment, 12(3), 189-201.

Widiger, T., Francis, A., Pincus, H., et al. (1992, 1994, 1996) DSM-IV Sourcebooks, Vols 1, 2, 3 (Washington, DC: American Psychiatric Association).

Widiger, T., Francis, A., Pincus, H., et al. (1997) DSM-IV Sourcebook, Vols 4 \& 5 (Washington, DC: American Psychiatric Press).

Zinn, H. (1970) The Politics of History (Boston: Beacon Press). 


\section{APPENDIX}

Youth psychiatric epidemiology, 1982-2004

\begin{tabular}{|c|c|c|c|c|c|c|}
\hline \multicolumn{4}{|c|}{ Mental health populations } & \multicolumn{3}{|c|}{ Juvenile justice populations } \\
\hline Reference $^{a}$ & Prev & ce $(\%)$ & Sample $(N)$ & Reference $^{\mathrm{a}}$ & ence $(\%)$ & Sample $(N)$ \\
\hline \multicolumn{7}{|c|}{ Conduct disorder } \\
\hline Berndt, 199 & & 10 & 4,229 & Atkins, 1989 & 40 & 75 \\
\hline Buckner, 19 & & 4 & 94 & Davis, 1991 & 81 & 173 \\
\hline Bukstein, 19 & & 70 & 156 & Davoil, 1982 & 82 & 71 \\
\hline Cohen, 199 & & $9-16$ & 734 & Garland, 2001 & 30 & 478 \\
\hline Costello, 19 & & d & 263 & Hlikas, 1990 & 81 & 114 \\
\hline Costello, 19 & & 3 & 4,500 & Hollander, 1985 & 85 & 200 \\
\hline Demilio, 19 & & 42 & 57 & McGarvey, 2000 & $50-62$ & 12,400 \\
\hline Garland, 20 & & 28 & 876 & McManus, 1984 & 11 & 150 \\
\hline Greenbaum, & 1991 & 36 & 812 & McPherson, 1991 & 50 & 64 \\
\hline Kashani, 19 & & 9 & 150 & Marsteller, 1997 & 35 & $\mathrm{n} / \mathrm{a}$ \\
\hline Pottick, 200 & & 31 & 4,000 & Milin, 1991 & 91 & 111 \\
\hline Rosenblatt, & $992^{\mathrm{b}}$ & 34 & $\mathrm{n} / \mathrm{a}$ & NCFCJ, 2004 & 9 & 1,215 \\
\hline Shaffer, 199 & & 12 & 1,285 & Office of Juvenile, 2004 & 32 & 296 \\
\hline Silver, 1992 & & 66 & 812 & Policy Design Team, 1994 & 52 & $\mathrm{n} / \mathrm{a}$ \\
\hline Stowell, 199 & & 54 & 226 & Shelton, 1998 & 40 & $\mathrm{n} / \mathrm{a}$ \\
\hline \multirow{2}{*}{\multicolumn{2}{|c|}{ Velez, 1989}} & $15-22$ & 776 & Teplin, 2002 & $38-40$ & 1,829 \\
\hline & & & & Timmons-Mitchell, 1997 & $96-100$ & 150 \\
\hline
\end{tabular}

Oppositional defiant disorder

Berndt, 1995

Buckner, 1997

Cohen, 1997

Costello, 1985

Costello, 1996

Garland, 2001

Kashani, 1987

Shaffer, 1996

Velez, 1989
4,229 Atkins, 1999

94 Garland, 2001

734 Office of Juvenile, 2004

263 Teplin, 2002

4,500

876

150

1,285

776
478

114

150

/a

111

215

296

$\mathrm{n} / \mathrm{a}$

829

150

\begin{tabular}{lrrrr}
\hline & mean $\mathbf{1 2}$ & total 12,907 & $\mathbf{1 2}$ & $\mathbf{2 , 6 7 8}$ \\
\hline CD+ODD & $\mathbf{2 2}$ & & $\mathbf{4 6}$ & \\
\hline Anxiety disorders/phobias $^{\mathrm{c}}$ & 18 & 11,156 & 29 & 2,587 \\
Attention-deficit hyper- $^{\text {activity disorder }}$ & 20 & 8,195 & 19 & 17,041 \\
Depression $^{\mathrm{c}}$ & & & & \\
Substance abuse disorders $^{\mathrm{c}}$ & 17 & 10,778 & 15 & 15,922 \\
Mood disorders $^{\mathrm{c}}$ & 12 & 5,506 & 46 & 7,211 \\
Psychotic $^{\mathrm{c}}$ & 17 & 1652 & 25 & 999 \\
\hline
\end{tabular}

a Lead author named. b With ODD. c Values from studies listed above. d 2nd most prevalent 